\title{
Electronic Commerce: A Taxing Dilemma
}

\section{Steven John Simon, Ph.D. Mercer University, Atlanta, GA, USA}

\author{
Simon si@mercer.edu
}

\begin{abstract}
In the last five years, remote selling-led by online organizations - has surged. The resulting growth has created concern among both traditional and remote sellers as they jockey for improved competitive position and governmental entities, in particular US states, over the erosion of their tax revenues as sales are diverted to remote sellers. This paper explores the issues and potential solutions surrounding the ecommerce tax dilemma. It provides a current assessment of the taxation environment for individuals and organizations impacted by the tax debate. Those individuals and organizations might include online business customers, remote sellers both traditional (mail order) and online, tax equity organizations, and governmental bodies. Current tax obligations are explored based on landmark legal decisions. Potential short and long -term solutions are assessed.
\end{abstract}

Keywords: Electronic Commerce, Taxation, Value Added Tax

\section{Introduction}

The Internet is a vast multinational framework comprised of more than 150,000 individual networks and used by more than 304 million people around the globe. The Internet's commercial as well as individual consumer use has skyrocketed since 1995. During these last six years, the Internet has spurred the development of new businesses, products, services, and enabled unprecedented innovation as well as new and less expensive methods for research and communication. For individuals, the Internet provides access to a virtually limitless amount of unfiltered information, consumer choices, and communication. The Internet has also opened a new (cyber) world of business - electronic commerce - for both consumers and businesses. For purposes of this report, "e-commerce," as defined in the Internet Tax Freedom Act, includes "any transaction conducted over the Internet or through Internet access, comprising the sale, lease, license, offer, or delivery of property, goods, services, or information, whether or not for consideration, and includes the provision of Internet ac-

Material published as part of this journal, either on-line or in print, is copyrighted by the publisher of Informing Science. Permission to make digital or paper copy of part or all of these works for personal or classroom use is granted without fee provided that the copies are not made or distributed for profit or commercial advantage AND that copies 1) bear this notice in full and 2) give the full citation on the first page. It is permissible to abstract these works so long as credit is given. To copy in all other cases or to republish or to post on a server or to redistribute to lists requires specific permission and payment of a fee. Contact Editor@inform.nu to request redistribution permission. cess." (Internet Tax Freedom Act 47 USC $§ 151$ section 1004 (3), 1998).

One of the greatest potential impediments to the future of e-commerce is the debate and uncertainty over taxation. The U.S. General Accounting Office (GAO) estimates sales tax losses from remote sales to be as high as $\$ 20$ billion in the year 2003 , or about $8 \%$ of all sales tax collected. The report, titled Sales Taxes: Electronic Commerce Growth Presents Challenges; Revenue Losses are Uncertain (Government Accounting Office, 2000) examined all remote sales, including Internet-based and other forms of remote selling. While the estimates vary the impact on state and local governments, which raise revenue via sales and use taxes, is staggering. Currently in the United States there are approximately 7,500 governmental bodies (state, country, city) that levy some form of sales and use tax. Across these agencies there is no uniform method for determining the amount of tax levied and no standardized method for the registration, collection, and payment of the taxes. Additionally, there has been an extensive legal debate over what is taxable, how much tax is owed, and what determines the legal obligations of businesses to charge tax to their customers. These issues have led to many companies being excluded or ignoring sales and use tax. As e-commerce grows this potential source of lost income increases as the existing revenue base decreases (as a result of the shifting economy and sales diverted to on-line sellers). As a result, state and local governments are striving to insure a key source of revenue does not disappear. 
This paper explores the issues and potential solutions surrounding the e-commerce tax dilemma. It provides a current assessment of the taxation environment for individuals and organizations impacted by the tax debate. Those individuals and organizations might include online business customers, remote sellers both traditional (mail order) and online, tax equity organizations, and governmental bodies. The paper is organized as follows. An examination of sales and use taxes opens the paper. Next, based on court cases, sales tax nexus (what determines if a company is responsible for charging tax) is discussed. The tax nexus discussion is extended to include global issues and the determination of what is taxable - an issue critical when considering digital downloads. A review of potential solutions to the e-commerce tax dilemma, within the current tax regime, is undertaken, followed by an examination of the value added tax scheme - a widely used procedure and potential replacement for the current system.

\section{Sales Tax Basics}

Sales taxes are "consumption-type" taxes designed to generate revenue. In general, these taxes are calculated and collected by businesses at the point of sale and remitted to the appropriate taxing authorities. Sales taxes have been levied throughout history, and became more widely applied in the United States beginning with the Great Depression. States' authority to levy these taxes is derived from the 10th Amendment of the United States Constitution which states, "The powers not delegated to the United States by the Constitution, nor prohibited by it to the States, are reserved to the States respectively, or to the people." Today, there are over 7,500 state and local governments levying sales taxes out of a potential $30,000 \mathrm{ju}-$ risdictions (Lilley and DeFranco, 1999). Local sales taxes are currently authorized in 33 states. Ordinarily imposed on the sale of tangible goods, the rates for these taxes range from $0.875 \%$ to $11 \%$ (Lilley and DeFranco, 1999). A small number of state and local governments also impose sales tax on some services, such as personal and repair services. Besides determining their own rates, states and, in some cases local governments define, classify, and exempt certain items within their tax codes. Many of these exemptions target necessities, such as food and prescription medicines. Throughout the year tax rates, definitions, classifications, and exemptions included in the sales tax code may be changed. State and local governments that levy sales taxes rely on them as a major source of revenue for their general funds. According to the United States Census Bureau, state and local governments collected approximately a total of $\$ 237$ billion in sales and use taxes in 1999 , comprising $24.8 \%$ of all revenues generated in that year (US Department of Commerce, 1999).

Sales tax is a tax on gross receipts from retail sales of products and services and is calculated as a percentage of the sales price. The sales tax regime is actually made up of two separate taxes, sales tax and use tax. The two taxes are intended to work in tandem to insure that tax is paid on ALL taxable retail sales. Sales and use taxes are usually applied using exactly the same tax rules and tax rates. The intent of the sales/use tax regime is for any taxable sales that fall through the sales tax net to be picked up and taxed under the use tax rules. However, the current tax regime falls far short of this goal.

Use tax is a tax on the use or consumption of a taxable product or service. It generally applies to the same kinds of taxable receipts as the sales tax. Use tax is meant to apply only if a sale has not been subjected to sales tax. This usually occurs only when the sales tax does not apply because the seller is outside the buyer's state. Use tax usually applies if the product or service is purchased remotely and used or consumed in the buyer's state. The seller must collect the use tax if it has nexus in the state. Use taxes are most commonly due when an item is purchased from a business in another state and the business does not have sufficient presence (nexus) in the consumer's state for the sale to be subjected to sales tax. In the event that a consumer purchases an item and the sales tax is not collected, the consumer is required to remit the use tax according to the location of consumption of the item. However, the rate of remittance of the use tax is low for business-toconsumer sales. One reason for these low collection rates is that taxing agencies have no practical means of identifying individual purchases or their consumers, making enforcement difficult and in many cases not cost effective. Most use tax remittances come from business-to-business sales where businesses are registered within the states and subject to audits. There is no conclusive data to indicate what the collection rates of the use tax would be on business-to-consumer sales if jurisdictions increased enforcement and public education of use tax obligations.

Sales tax is imposed on gross receipts from the sale or lease of tangible personal property (TPI), unless the property is specifically exempted from tax. That is, all TPI is taxable, unless an exemption has been provided. Services, on the other hand, are not taxable in most states unless made taxable on a service-by_service basis. For instance, a state may provide that services are generally not taxable, but that computer services or professional services are taxable. Sales tax ordinarily arises when a seller and buyer are in the same state. In most states, sales tax is imposed on customers but collected by sellers, though in some states, tax is imposed directly on sellers. Whether the tax is technically imposed on the buyer or seller usually has no practical effect on the way a sale is taxed.

The sales tax issue involves not only questions about states in which sellers must collect tax - it involves determinations of what is taxable. Under the rules of all states that 
impose a sales tax, most tangible personal property is taxable, but only selected services are taxable. We know that products delivered in boxes are tangible personal property, but what about products delivered electronically, such as software, books, or music? States have not issued complete rules on whether electronically delivered products (digital products) are tangible personal property, and therefore taxable. The rules that have been issued are wildly inconsistent from state to state. Sales tax is usually collected only on sales of tangible personal property (TPI). Usually, all sales of TPI are taxable, unless a state's tax code provides a specific exemption. One such exemption is for food, which is typically not subject to sales tax. Some TPI is exempt from tax at certain times of the year. For instance, a state may exempt clothing from tax during the "back-to-school" buying season. In other cases TPI is exempt based on price. For example, an article of clothing might be exempt if it is priced at less than $\$ 100$. The definition of TPI has become somewhat unsettled with the introduction of new electronically delivered products. When a product can be delivered either through the mail or electronically, its classification as TPI when delivered electronically is unsettled.

Services are usually not subject to sales tax unless a state's tax code specifically provides for taxation. Some states are like California and tax only a handful of services. The states of Hawaii and New Mexico, on the other hand, tax a long list of services. With the Internet new services have arisen, some of which are taxable in some states. These include, in some states, Internet access services, online access to entertainment, research services, online advertising services, and online professional services. The Internet Tax Freedom Act (ITFA) prohibits taxation of some online services.

The key to sales (and use) tax is the location of the sale. There is some consistency among the states in determining the location of sales. Sales are ordinarily taxed in the states in which products or services are delivered, used, or consumed. This rule usually applies regardless of where the buyer is located, or where the sale is billed. While the rule for sourcing product sales seems simple enough, it is not. For instance, where goods are shipped from one state to another the delivery-state rules says that the sale is taxable in the state to which the goods are shipped. However, some states have determined that, based on the terms of the sale, the sale is taxable in the state from which the goods are shipped. In these cases, the state from which the goods are shipped and the state to which the goods are delivered may both attempt to tax the sale.

States have their own rules for determining whether a product is taxable in the state. California, for instance, will not consider a sale taxable in the state even if it is delivered to the state, so long as the product is present in the state for only a short period of time and substantial use of the product takes place elsewhere. Problems can arise when a single product is used in multiple states. For instance, a multistate organization may purchase software and install it on a server in one state with the intention of enabling business locations in other states to simultaneously access the software. The question arises over which state should collect sales or use tax, and which states should self-assess use tax.

The sourcing of services, especially online services used in multiple locations, can present real problems for both sellers and buyers. The various states have issued few rules to tell us what state should tax a multistate sale of online services. A major problem is the potential for a mismatch between the location where an online service is billed and where it is used. For instance, buyers may use services in different locations, accessing services from different computers. Or, one buyer may purchase a service, but allow someone at a different location to use the service. The mismatch of the use and billing locations for nonbusiness consumers is not likely to be a problem, since most use by an individual consumer is likely to take place at the consumer's billing address. More serious is online access to a service or digital product by multistate businesses. For instance, it is likely that an online service will be billed to one location, but be used in other locations - possibly in states other than the state to which the service is billed. The seller may collect too little or too much tax, while the buyer may be subject to double taxation.

\section{Tax Nexus}

A retailer must collect sales and use tax in a state if it has physical presence in the state, or if it has an agent in the state. Any physical presence in a state is enough to cause a company to have sales tax "nexus" in a state (to have sales tax nexus in a state is to have a sufficient connection with a state to justify the state requiring the company to collect tax). The issue of tax nexus is one that affects all business including traditional brick-and-mortar, mail-order, cyber companies, and the evolving bricks-and-clicks. This section focuses on the issues which establish a firm's tax nexus.

The inability of state and local governments to require remote sellers to collect use taxes can be traced back to a line of United States Supreme Court cases that established the "substantial nexus" standard (Quill Corp. v. North Dakota, 504 U.S. 2981992 and National Bellas Hess, Inc. v. Dept. of Revenue of State of Illinois, 386 U.S. 753, 1967). These cases point to the Commerce Clause of the Constitution and Congress' role to regulate interstate commerce as the basis for restricting states from forcing out-of-state sellers to collect use tax. With the explosion of ecommerce, there are concerns that an increasing number of 
consumers will purchase items through remote sales channels such as the Internet and catalogues, and sales tax revenues from face-to-face sales may diminish.

Tax nexus is based on the statue of physical presence - the location of a company, its facilities, or employees - in a state or tax locality. Physical presence results in sales tax nexus, even if the purpose of the in-state presence is unrelated to selling activities. In the case National Geographic vs. California (430 US 551), the presence of employees in California was enough to create sales tax nexus, even though these employees had nothing to do with the sales in question. In this case, the employees worked for the magazine division of National Geographic, while the sales were made by the mail-order division.

In a number of mail-order cases, the states and their taxing authorities used a variety of arguments to try to convince the courts that presence in the state of an affiliated company or a representative caused a mail-order company to have sales tax nexus. States argued, among other things, that a mail-order company had economic presence in a state, or that it was part of a unitary group (discussed later) of businesses that included stores in a state. However, the courts invariably decided the nexus question on the basis of whether an affiliate or representative in a state was the agent of the mail-order company. These cases are directly applicable and set the precedent for cyber and hybrid companies.

In Bloomingdales vs. Dept of Revenue (527 Pennsylvania $347,1991)$, where an out-of-state mail-order company was related to a company that operated stores in Pennsylvania, the issue of whether the in-state stores caused the mailorder company to have Pennsylvania nexus was decided based on whether they acted as agents for the mail-order company. The court found the issue to turn on whether the parent company acted as an agent for the mail-order company. In another case, Reader's Digest vs. Mahin (44 Illinois 354,1970 ) the court found the agency relationship critical to the nexus analysis in a case involving affiliated entities. Hence, a sufficient nexus was established because the mail-order's subsidiary which was present in the state also acted as its agent in the solicitation of advertising. (Current vs. SBE, 24 California Applet 382, 1994).

The issue of what is and what is not an agent was explored in depth by a California court in Scholastic Book Club vs. SBE (207 California Applet 734, 1989), a case involving school teachers who sold books to their students on behalf of an out-of-state company. The court found that the teachers acted as agents of the out-of-state company, even though there was no formal principal-agent relationship. In Scholastic, the mail-order company used local teachers as conduits to its customer base. Similarly, an out-of-state seller may depend on local stores. Indeed, without local stores acting on its behalf, the online retailer's ability to create and maintain a good relationship with its customer base may be hampered. This is especially true in the case of products that require after-sales service, such as computers or consumer electronics. If an out-of-state retailer regularly uses local stores as its in-state representatives there is a strong indication that these stores are agents for the company, and that the company has sales tax nexus in the state.

Recently, a number of cases established precedence for online retailers. In Louisiana v. Quantex Microsystems, Inc. (Docket 2000 CA 0307 Louisiana Court of Appeal $3 / 31 / 01$ ), the courts in a summary judgment found that an out-of-state corporation's use of independent contractors to provide on-site computer repair services cannot constitute substantial nexus. This case establishes the distinction between employees and independent contractors. In America Online v. Johnson (Docket 97-3786-III Tennessee Chancery Court 3/13/01), the state of Tennessee attempted to establish AOL's nexus in the state based on economic presence in the form of large numbers of AOL CDs distributed in the state and the location of leased telecommunications equipment. The courts rejected both arguments, stating that leased equipment did not substantially contribute to AOL's ability to maintain operations and that CDs were an insignificant factor in determining nexus.

In summary, the courts have decided that there must be a specific and direct relationship between the firm and its employees or agents to establish substantial presence resulting in tax nexus within a state. An arrangement between a firm and independent contractors performing a service for a company does not meet the court's substantial presence requirements and therefore, no tax obligation exists.

\section{Merchandise Returns}

An executive of Barnes and Noble, Inc. recently said that one of the things customers of its online store, bn.com, most wanted was the ability to return unwanted merchandise to local stores. Since its inception, bn.com had required its customers to return merchandise by mail to its own distribution center. To satisfy customer demands, bn.com has changed its policy and now allows customers to return products by mail or to local Barnes and Noble stores. Some claim that the acceptance by a local store of returns of merchandise sold by an online affiliate causes the store to be the agent of the online affiliate. Generally, this argument failed in the mail-order cases because courts found in these cases that by accepting merchandise returns, the local stores were acting on their own behalf, not on behalf of their mail-order affiliates. Thus, the stores were not acting as agents. 
When a store accepts returns of merchandise purchased from a related online company, the question is whether the company is acting on its own behalf or as the agent of the online company. If a store acts on its own behalf, its actions will not be those of an agent and will not cause the related online company to have sales tax nexus in the state in which the store is located. On the other hand, if the store accepts returns on behalf of the online company, it is clearly acting as an agent. When a store accepts returns of merchandise sold by a related online company, it appears on its face that the store is acting on behalf of the online company.

Where the store takes a return to keep a customer happy, it is acting on its own behalf. While the customer may have purchased a particular item online, that same customer undoubtedly has, or will in the future, make purchases from the local store. Indeed, a customer who returns merchandise may make a replacement purchase at the time of the return. If the customer makes such a purchase, the store has not only broken even on the deal, but has either maintained the goodwill of an existing customer or has found a new customer. Therefore, where the policy of an online company is to take returns by mail, and where the customer instead returns the merchandise to an affiliated store, the store may be acting on its own behalf by taking the returns. Thus, the fact that a store takes returns does not mean it is the agent of a related company. Instead, an inquiry must be made as to why the store takes the returns.

While a store may act on its own behalf in taking returns, it may also act as the agent of a related online store. This can be the case where customers of a remote seller are asked to and even encouraged to return merchandise to a store. Where a store is obligated to accept merchandise returns from customers of another company there appears to be an agency relationship. If merchandise is accepted by a store, returned to a warehouse, and added back to the inventory of the original seller, SFA Folio Collections vs. Tracy $(73$ Ohio 119, 1995) does not seem to apply. It is important, therefore, to understand exactly what happens to merchandise returned to a store. If the merchandise is returned to the online company there is an indication that the physical store is acting as the online company's agent in accepting the returns.

\section{Other Issues and Considerations}

The effect of a Web server in a state is one of the most pressing issues for online sellers, since every company needs a server and it is often necessary to use a server in another state. The issue is important enough that several states have issued guidance on the effect of a Web server in a state. California says use of a Web server in the state to host a website does not in itself result in nexus. The rule does not say anything about a company owned or leased
Web server in a state, leaving open the possibility that ownership or lease of an in-state Web server can cause nexus. Oklahoma has rules similar to California, which protect a seller from nexus where a Web server in the state is used to host a website. Once again, ownership or lease of a server may not be protected. A variation on website hosting arrangements is a virtual mall, where an unrelated company not only hosts a website, but provides certain services, such as transaction processing. States indicated that the hosting of the site alone is not grounds for the establishment of tax nexus. For businesses, the problem involves the services provided by the web site host. A recent poll of tax administrators conducted by $\mathrm{CCH}$, a major publisher of tax related materials, found that services such as design, advertising, and transaction processing resulted in tax nexus.

In a case between Quill Corp and the state of Texas, the presence of software within the state was used as grounds for physical presence. Texas claimed that, based on Quill v. North Dakota (504 US 298, 1992), forty copies of software licensed to customers in the state was sufficient to cause tax nexus. A number of other states agree with the Texas position. It is unlikely that the courts will find on behalf of Texas in this case, as a result of America Online, Inc. v. Johnson (Docket 97-3786-III Tennessee Chancery Court 3/13/01), discussed earlier, where the courts found that AOL's software on computers and disks provided by mail failed to establish substantial presence.

\section{What is Taxable?}

So far this paper has provided insights into the legal requirements that establish a firm's tax obligation and the type of tax that a firm might be expected to pay. The discussion applies to all firms regardless of their organization structure or the method they choose to transact business. If these issues were the entire domain of electronic commerce, the taxation issue might be easily resolved. That is not the case. Electronic commerce, especially with regard to delivery of services and intangible items, has opened "pandora's box" by providing the ability to delivery directly to the customer formerly traditional tangible products which are now considered intangible goods or services. This impacts the tax discussion since the majority of the state tax codes state that all tangible personal property is taxable.

Consider the case of a company that sells products such as music, books, software, or video. If the firm sells to a customer and delivers a tangible product (e.g. CD, diskettes, video tape, etc) via traditional means (mail or private carrier) and has substantial presence in a state (as indicated above), the customer/company is obligated to pay sales tax on the value of the tangible item delivered. If on the other hand, the same company sells the same item to the same 
customer but delivers the product electronically, there is a question if the product is tangible property that is taxable. This has created a dilemma for businesses and states alike since the instance of electronically delivered products is increasing and most states have not incorporated these items and transactions into their tax codes. Another area of concern is the ramifications for global trade since these transactions ${ }^{1}$ are impossible to track because they do not cross traditional geo-political borders.

This issue has been addressed by the Technical Advisory Group (TAG) of the Organization for Economic Cooperation and Development (OECD) ${ }^{2}$ in a report titled Treaty Characterization Issues Arising from E-Commerce (OECDa, 2001). The TAG found that most of the controversy in characterizing e-commerce is between classifying payments resulting from digital transactions as either business profits or royalties. This is a key distinction because the taxation of business profits and royalties can differ greatly. In transactions involving two treaty countries, business profits are taxable in a country only if they are associated with a permanent establishment (equivalent to substantial presence in the United States) in that country. On the other hand, royalties arising in a country are often taxed in the country regardless of whether there is a permanent establishment. The definition of royalties used by the TAG is found in Article 12 of the OECD Model Tax Convention, "payments of any kind received as a consideration for the use of, or the right to use, any copyright of literary, artistic or scientific work including cinematography films, any patent, trade mark, design or model, plan, secret formula or process, or for information concerning industrial, commercial or scientific experience."

The TAG found that most digital transactions did not result in royalties. This is because most of the transactions did not involve the use or exploitation of intellectual property. Initially, some members of the TAG argued that many digital transactions resulted in royalties because of the way digital transactions took place. Digital transactions usually involve the copying of digital files housed on Web servers, where a copied file is transmitted electronically to a user or customer. In some countries the act of copying a digital file, such as software or music, amounts to a use of copyrighted material. In these cases, under a formalistic interpretation of a transaction, a royalty might result from the

\footnotetext{
${ }^{1}$ The domain of intangible product transactions is much greater than software and entertainment products and include architectural services, insurance, bank and stock transactions, medical, and consulting services to name a few.

${ }^{2}$ The United States is a member of OECD.
}

payment for the right to use the copyrighted material. However, the TAG rejected a formalistic analysis of digital transactions, choosing instead to focus on their substance. Examination of the substance of most digital transactions showed that the use of a copyright is not involved. Instead, the act of copying digital materials is incidental to the transactions, and should not affect their characterization.

The TAG finding does very little to resolve the domestic issue of taxation of digitally delivered products and services. Since they are still considered intangible in nature, there exists no physical/tangible product to assess a tax upon. Additionally, the ability to track a transaction of this nature is just being developed. The next section will extend this debate by examining other issues of global electronic trade.

\section{International Issues}

The essence of electronic commerce is remote selling. A vendor, whether $\mathrm{B} 2 \mathrm{C}$ or $\mathrm{B} 2 \mathrm{~B}$, does not create a Web site to sell locally. An e-commerce company is as likely to sell to a customer in another country as to one down the block. The change from a local to an international customer base is remarkable, and its effects on selling are still not known. As electronic commerce causes more interstate and international transactions, remote sellers must deal more often with the laws of other states and countries whose laws were written primarily for local buyers and sellers. Most laws were enacted to address uniquely local problems or attitudes and not written with foreign sellers in mind, yet it is these local laws with which remote sellers must comply.

As international commerce becomes commonplace, there is a general trend to get worldwide agreement on laws that affect remote sellers. A good example is the work by WTO (World Trade Organization) to gain worldwide consensus on legal protection of intellectual property, an issue critical to the growth of e-commerce (see Table 1 for goals and objectives). Equally important is a trend to get consensus on tax rules that affect international transactions. There is an international trend toward harmonization of the tax rules that affect e-commerce.

\section{Table 1}

\section{Goals of International Tax Harmonization}

Prevent tax evasion

Close interstate and inter-country loopholes

Decrease tax competition

Ease the tax compliance burden of remote sellers

Protect remote sellers from double taxation 
Outside the United States, the predominate tax mechanism is the value added tax (VAT) [discussed in the next section]. In 1998, finance ministers from around the world met and discussed tax rules/changes needed for the "new economy" and in particular electronic commerce. The meeting resulted in two key findings: that digital products should be characterized as services and that the VAT should be changed to collection at the place of consumption, rather than the place of supply

(www.oecd.org/daf/fa/e-com/Ottawa.htm).

The work on income characterization is the first to have potential impact on the harmonization of tax rules. The initial recommendations of the TAG (Technical Advisory Group from the Finance Minster Meeting) working on this issue focus on characterizing income from sales of digital products. These are products and services that can be delivered electronically through the Internet. Because these types of transactions so easily cross international borders, their volume is likely to grow, and it is important to set down consistent tax rules early. The TAG has made recommendations that differentiate those digital transactions that result in royalties from those that result in business profits. This distinction is important because royalties are almost always taxable in the customer's country, whereas business profits are taxable in the customer's country only if the seller is established and doing business in that country.

This difference in treatment sets up a conflict between those countries, such as the United States, that are net exporters of digital products and services, and those countries that are net importers. Exporters prefer rules that characterize digital products and services as business profits. Because sellers of these digital products and services tend not to be established in customer countries, they will not be taxable in those countries. Instead, the seller's own country will retain jurisdiction to tax these profits. On the other hand, countries that are net importers of digital products and services prefer rules that characterize sales as royalties. These countries retain the right to tax royalties paid to foreign sellers by their own residents. Clearly, without consistent rules, both exporter and importer countries might claim the right to tax the income from sales of digital products and services. This would be a disaster for sellers, and an impediment to the growth of e-commerce.

Unlike the sales tax which is collected at the point of sale, the value added tax (VAT) is collected at each step of the "manufacturing" process (more details in the next section). In theory, a product imported into an EU country would be taxed at a VAT rate equivalent to if it had been manufactured in that country. While this arrangement might be acceptable for tangible products, an agreement for intangible or digital products has yet to be reached. The European Union's VAT has similar problems to the sales tax in the United States. Across the EU the VAT rates vary - by country - from $15 \%$ to $25 \%$ which creates the same dilemma for importers that businesses have with sales taxes in the United States. The EU Commission (www.eu2001.se) Ministers Meeting in 2001 suggested a series of proposals which included simplifying tax rates, collection schemes, and allowing non-EU companies to register in a single EU country. These proposals were viewed by some countries as usurping their powers to tax. Their feeling was that non-EU companies would register in the country which had the lowest rate and least restrictive tax regulations (OECD, 2001b). As a result, EU companies would find themselves at a significant disadvantage to their non-EU competitors, which is the key argument between companies conducting electronic business and those that do not. An alternative proposal suggested a short term moratorium on e-commerce supplies to EU consumers. To date, the proposals of the Minister's Meeting have been unacceptable even to the Europeans, with many agreeing that the mechanisms to monitor and collect the tax are too complicated.

Europe's efforts to contain the e-commerce taxation situation are similar to those in the United States. Globally, all countries are attempting to resolve the issue and in some cases are trying to limit e-commerce activities within their borders. The next section examines some possible alternatives.

\section{Solutions}

This paper has reviewed the issues of taxation and electronic commerce (mainly from the US domestic perspective). This section explores some of the potential solutions. These potential solutions include the issues surrounding the cost of tax compliance (determination of tax nexus, large numbers of sale tax rates, and the means through which to collect and disburse the tax payments) plus other potential taxation options. Clearly no person or company wants to pay taxes, especially if the act and cost of compliance is extremely high and time consuming. As a result, federal and state governments, non-governmental organizations, and industry groups are working to create a tax system that is fair and relatively easy to comply with. These organizations and agencies have created a number of proposals designed to make the issues surrounding nexus clear and easy to apply and streamline the existing tax system. Some of those proposals are discussed in this section.

\section{Tax Nexus}

The United States Congress has introduced the Internet Tax Fairness Act of 2001, otherwise referred to as HR2526. HR 2526 establishes "substantial physical presence" (SPP) as a minimum threshold for Business Activity Tax (BAT) nexus. (BAT includes state income tax and 
other direct taxes.) To have nexus means to have sufficient presence in a state to allow the state to legally impose tax. A SPP requirement would mean a seller must have physical presence in a state before the state can impose a BAT and presence must be substantial (though the term substantial is not defined). In addition, for sellers that have SPP, the bill provides a number of safe harbors that can be used to avoid nexus.

Supporters of a SPP test claim that it will be an easily understood standard, will eliminate costly litigation, and will inhibit overly aggressive state tax collectors. The Bill attempts to justify a physical presence standard by stating that a state cannot impose a tax on a seller if the state does not provide benefits to the seller. Supporters claim services provided to remote sellers are minimal, and do not justify the imposition of tax. This leads to an argument about the extent of services a state provides to a remote seller, for which the state can exact a tax. Opponents of a SPP rule cite a list of services provided to remote sellers by states. Generally, a tax cannot be imposed by a state unless it is fairly related to services provided by the state (Complete Auto Transit, Inc. v. Brady, 430 U. S. 274 1977). However, as explained by the Supreme Court in Commonwealth Edison v. Montana (453 U.S. 609 1981),

"A tax is not an assessment of benefits, it is a means of distributing the burden of the cost of government. The only benefit to which the taxpayer is constitutionally entitled is that derived from his enjoyment of the privileges of living in an organized society, established and safeguarded by the devotion of taxes to public purposes. Any other view would preclude the levying of taxes except as they are used to compensate for the burden on those who pay them, and would involve abandonment of the most fundamental principle of government -- that it exists primarily to provide for the common good."

This language indicates that a state can meet its burden of showing that a tax is fairly related to services provided, so long as it provides some level of service to an out-of-state seller. States are not required to provide taxpayers with an itemized list of services provided before tax can be levied. At least in the courts, a requirement that a state provide substantial services to an out-of-state seller before it can exact a tax probably does not exist.

There is no ready solution to the question of whether the value of benefits provided to remote sellers equals the tax states seek to impose. The deliberation of what is a fair and equitable tax for the service provided could extend into infinity. For business and government, the best possible outcome of HR 2526 is the establishment of relatively simple and enforceable rules that establish clear guidance of business tax nexus.

\section{Streamlined Sales Tax Project}

As illustrated earlier in this paper, there are currently 7500 governmental bodies which are imposing some form of sales or business activity tax. As a result, businesses often find that they have multiple sales tax rates to administer in a relatively small geographic area. For instance, most states charge a single sales tax rate and in addition, counties/parishes, cities, and even unincorporated areas add a variety of surcharges. The issue is even more complicated when exemptions and consumer holidays are added into the equation. This creates a monumental task for businesses which conduct transactions over large geographic areas, with the burden especially severe for small businesses. One means of simplifying the tax codes and hence improving the chances of compliance is the Streamlined Sales Tax Project (SSTP). The rules of SSTP serve as models for new laws where states operate under a constant set of rules and, like HR 2526, the compliance burden on sellers is substantially reduced.

The primary goal of the Streamlined Sales Tax Project (SSTP) is to simplify state sales tax. Simplification is to come about mainly by making states operate under a single set of rules. The SSTP has been underway for almost two years and has so far produced two primary documents, the Uniform Sales and Use Tax Administrative Act and the Streamlined Sales and Use Tax Agreement. By adopting the Act into law, state tax authorities are authorized to enter into an Agreement with other states. The Act authorizes tax authorities to represent the state in negotiations with other states in the implementation of the Agreement. The Agreement is a document that provides the rules under which participating states and sellers will operate and provides a uniform set of sales tax rules and procedures that Member States agree to abide by. It has no direct effect on state law, and has no effect on sellers. Instead, states must amend their own laws to conform to the requirements of the Agreement, and to cooperate with one another. Since state courts continue to interpret tax laws, the potential exists for variance in the rules. The Agreement takes effect when five states have signed it.

One of the main reasons for entering into the Agreement is to get remote sellers to voluntarily collect tax. Currently, a seller is not required to register for and collect sales and use tax in a state unless that seller has physical presence in the state. Because most remote sellers have physical presence in only a few states, these sellers register to collect tax in only a few states. By agreeing to simplify sales tax compliance in accordance with the Agreement, and by offering other incentives, states hope to convince these sellers to voluntarily collect tax. Another incentive offered to remote sellers by SSTP is the limitation of local control over sales taxes. Of the 7500 jurisdictions that currently impose some form of sales tax, only 46 of these are states. 
The remainder are local tax jurisdictions. Many of these local jurisdictions have nothing to do with setting rules for sales tax. They do not require separate filings by sellers, and they do not impose special rules that are different from those of other jurisdictions in the same state. They simply impose a tax which is added to the state level sales tax, but which is calculated using the same rules as the state level tax. In order to enter into the Agreement, states must enact laws that limit the power of local jurisdictions to act independently of the state.

Additionally, the Agreement examines the issue of sale location. For sales of tangible property, most state tax rules deem a sale to take place where the item is delivered. However, this is not always the case. For sales of services, states have different rules as to where the sale takes place. Some states locate sales of services at a customer's billing address, while other states take different approaches. SSTP takes the position that goods or services are generally taxed where they are received. At times an address is unknown as is the case of digital transactions. In this case, the tax is applied at the point of delivery, potentially the location of the downloading server. Also examined is the issue of consistent tax base. The tax base is the universe of goods and services subject to tax in a jurisdiction. Because each state has a different tax base, and because some local jurisdictions have defined their own tax bases, determining what is taxable in a jurisdiction by national sellers is very difficult. To establish some consistence across states, the agreement provides definitions of products commonly subject to taxes including refining categories of goods (eg food, clothing, etc). The Agreement unfortunately does not provide a definition of tangible personal property. Since most state tax laws say that only tangible personal property and selected services are subject to tax, a failure to define tangible personal property is a major shortcoming of the Agreement.

In summation, the SSTP provides incentives to both taxing authorities and sellers. While the Agreement and Act are not without shortcomings and opponents, it is a viable first step to streamlining the e-commerce tax dilemma. Combine with HR 2526, the SSTP demonstrates the level of interest and gravity of the situation. The SSTP is in constant evolution. Updates and revisions are continuously posted at the organization's web site

(www.streamlinedsalestax.org). No matter how tax nexus and tax rates are refined, tax compliance systems must be simplified in order to reduce the burden on all sellers, especially small business. The next section explores automated compliance systems.

\section{Automated Tax Collection}

In addition to simplifying the issues of tax nexus and multiple tax rates, the most pressing issue for businesses is the creation of a system that would reduce the burden of collection and payment of sales and use taxes. The SSTP has recognized this requirement and has incorporated it into the registration process for business and Member States. As a result, sellers must adopt an automated tax collection and payment system. This section examines the three prototype systems.

Sellers can select one of three models listed below:

Model 1 - Sellers can contract with Certified Service Providers, who serve as seller agents to collect and remit tax. Use of a CSP shifts responsibility for collection and remittance to the CSP.

Model 2 - Sellers that do not wish to use a CSP can use a Certified Automated System (CAS). This is essentially a software solution, licensed by the seller, which as been certified by the Member states.

Model 3 - A large seller can use a proprietary system that has been certified as a CAS. A large seller is generally one with over $\$ 500$ million in annual sales; however, Member States can agree to a lesser amount.

Certified Service Provider. The SSTP envisions a radical departure from the current practice of sales tax administration. Member States will allow sellers to delegate to unrelated third parties the responsibility of collecting sales tax. These third parties are known as Certified Service Providers, or CSPs. A CSP is the agent of the seller, but it is more than that. The seller is able to transfer the responsibility for sales tax collection to the CSP for all transactions processed through the CSP. So long as the seller is honest in its dealings with the CSP (e.g., does not misrepresent the items it sells, and does not commit fraud), the seller cannot be held liable for the tax on these sales, and is not subject to audit of these sales. Of course, the seller remains liable for taxes not processed through the CSP, and remains subject to audit on these sales. The states, acting jointly, can perform a check on a seller's system to make sure that it is functioning properly. So, the seller that processes all of its sales through a CSP is not completely off the hook. However, this is a far cry from the intense scrutiny undergone by a seller that is subject to a full sales tax audit, and especially where the seller is subject to audits by multiple states.

Certified Automated System. Part of streamlining the country's sales tax system is the development and certification of sales tax compliance software. Already several companies make software that is used for tax collection. The plan is to set up a mechanism to certify the software. Where certified software is used, the software company becomes liable to Member States for errors in the functioning of the 
software. In addition, the seller remains liable to collect and remit tax.

Large Company Proprietary System. The largest companies will be able to use their own software. Many of these sellers have spent considerable amounts on developing proprietary systems, and will wish to continue them. These systems are liable to meet certain performance standards to be set by Member states.

\section{Pilot Test of CSP}

Currently the Certified Service Provider (CSP) and an automated software solution is in test in four states. The package was created jointly by Taxware and HewlettPackard. The solution works by receiving sales information via the Internet from sellers, calculating the sales tax, and sending the tax information back to the sellers. The seller remains responsible for these sales. Sales to the participating states will be channeled through the CSP system, which assumes responsibility for tax collection and remittance. Customers should be unaware of how the tax collection function is performed.

The CSP system calculates sales and use tax for both Internet and traditional transactions, and remits the tax collected to the states involved in the pilot. That is, sellers can process both online and offline sales through the CSP. After calculating the tax, the CSP will ordinarily debit the amount of tax from the seller's bank account and remit this amount to the participating states. Taxware claims the CSP system will work with existing online order-entry systems such as ERP systems. In addition, the system is designed to accommodate the way sellers bill their customers. For instance, if a seller does not charge a credit card until a product is shipped, the CSP system will not debit the seller's bank for the tax until the product is shipped and the credit card is charged. Taxware and H-P are aware of the need for rapid response, and have engineered the system to reduce potential delays by employing multiple servers in different geographic locations.

\section{Global Initiatives}

The pace of cross-border transactions is accelerating, due in large part to electronic commerce as business buyers search marketplaces around the world for the best price, quality, and service. In addition, pressure to reduce transaction-processing costs continues to mount as a worldwide business slowdown squeezes profits. Set against this trend toward broadening and streamlining the supply chain are entrenched state and national tax systems. For important political and fiscal reasons, these systems respond more to local than global pressures. In the global arena, especially within the European Union, efforts mirror those in the United States. The European Union has proposed an initiative to shift from paper to electronic VAT invoices (the documents that support a firm's tax basis). The proposal is aimed at removing the paper burden businesses suffer but which are currently prone to fraud. This initiative is found as part of the EU proposal on VAT invoicing (http://europa.eu.int/comm/taxation customs/index en.ht $\underline{m})$. Incorporated into the proposal are requirements to harmonize the form and contents of the VAT invoices of the Member countries. The proposal depends on the use of electronic signature technology to minimize fraud and insure security by identifying the invoice issuers and guaranteeing that the contents of the invoice have not been altered. This proposal would allow large firms to transmit VAT invoices via EDI and eventually, small firms to use XML-based systems.

A recent study sets the cost of handling a paper VAT invoice at between ECU 1.13 and 1.65, while the cost of an electronic invoice is between ECU 0.28 and 0.47. Coinciding with the trend toward automation is the centralization of transaction-processing functions. The study also describes how it can cost $\$ 9.50$ per invoice to process 10,000 invoices at a single site, and that the combined cost of ten such sites is $\$ 9.5$ million. However, if all 100,000 invoices are processed at a single site, the cost falls to $\$ 5.50$, for a total cost of $\$ 5.5$ million, and a savings of $\$ 4$ million (PriceWaterhouseCoopers, 2001). For B2B transactions ERS (evaluated receipts settlement) is another system aimed at trimming costs. ERS eliminates the need for a seller invoice. The elimination of the seller invoice saves both the seller and buyer the cost of handling the invoice. By self-invoicing, buyers are able to speed the processing of a payment, enabling them to take advantage of vendor discounts for fast payment. Also, without an invoice there is no need to reconcile the invoice sent with the goods received - always a time consuming process. Centralized ERS software is currently under development for multinationals. One example is TaxBay (www.sabrix.com).

Up to now, the paper has examined the issues surrounding electronic commerce taxation and some of the potential solutions to resolve those issues. These solutions have so far worked within the existing system of taxation - tax nexus and sales taxes. There exist alternatives to the existing tax regiment which include a national retail sales tax system, flat tax, value added tax (VAT), and savings inspired tax schemes (Gale 1995). Of all the suggested alternatives, the most widely implemented (globally) and recommended for the United States is the VAT. The following section provides a detailed examination of the VAT and its potential advantages and disadvantages for US implementation.

\section{Value Added Tax}

Value added taxation (VAT) has become the standard form of sales tax throughout most of the world: Western Europe, 
Latin America, Canada (as of 1991), Korea, Japan, much of Africa in simplified form, and now the Caribbean. A value-added tax, or VAT, taxes the value added in production through the various stages of production. Value added is simply the difference between the value of the goods (or services) sold and the value of goods (or services) purchased as intermediate inputs. There are several ways to impose such a tax. Countries could tax gross sales net of intermediate goods purchased at each stage of production. This forms the basis for a subtraction method VAT. A second method of imposing a VAT would be to tax gross sales and allow a credit for taxes paid by other firms at previous stages of production on intermediate goods. The credit method VAT works in this fashion. Under the addition method, a company's VAT base is primarily untaxed inputs (wages, salaries, depreciation, profit, etc). The base is simply multiplied by the tax rate. The most common way of administering a VAT is to levy a tax on the total value of sales at each stage of production and allow a credit for any VAT paid on inputs in production. For purposes of claiming the credit, a firm is typically required to show proof (usually an invoice) that the VAT has been paid by its supplier. This provides a form of self-regulation in VAT enforcement, since firms have an incentive to ensure that the VAT that their supplier claims to have paid has in fact been paid (Metcalf 1995).

Pechman (1987) attributes the modern idea of value-added taxation to a post-World War I German industrial executive. France was the first European country to adopt a limited VAT in 1954; the form was a wholesale-level VAT to replace a multi-stage production tax. With the formation of the European Community (EC), the European Economic Community (EEC), and the interest in tax harmonization within Europe, greater attention was paid to the variety of production taxes that existed in Europe. The original Treaty of Rome that established the EC in 1957 called for consideration of tax legislation that would harmonize the members' tax codes. Ten years later, two directives were adopted by the Council of Ministers that led to VATs being implemented by member countries. The first directive called for the replacement of the existing system of cumulative (that is, cascading) taxes with a noncumulative VAT, and the second directive laid out ground rules for constructing VATs. Additional directives were adopted that clarified various issues with respect to VAT taxation. Finally, in 1977, the sixth directive on VAT brought together the various previous directives on VAT and established consistent rules for VATs in the EC. Subsequent countries that have joined the EC (Greece, Portugal, and Spain) have introduced a VAT. As the European Community moves toward a single market, harmonization of tax rates is increasingly important (Buckett, 1992).

Canada and Japan have also introduced some form of value-added taxation. Japan introduced a subtraction style
VAT in 1989. It differs from a standard VAT in allowing firms to take a credit for purchases from exempt businesses despite the fact that no VAT was paid on those purchases. Roughly two-thirds of all businesses in Japan are completely exempt from the VAT, and additional businesses are partially exempt (JCT 1992). This credit has the effect of lowering the tax burden and creating an incentive for Japanese firms to purchase from tax-exempt domestic businesses rather than from importers (who do not receive the credit). Canada introduced a federal VAT called the Goods and Services Tax in 1991. Unlike a typical credit style VAT, the Goods and Services Tax is levied on the purchaser with vendors responsible for collecting the tax. In this sense, the Goods and Services Tax is a federal sales tax.

In the US the VAT is not without its detractors. Some claim that the VAT is regressive, in that the tax burden is placed $100 \%$ on the final consumer with a greater proportion borne by the poor, the elderly, and those who consume the majority of their income. Some economists argue that the VAT is regressive only on an annual basis and over one's lifetime the tax is proportional to income earned. Suggestions for limiting the regressivity of the tax include exemptions or zero-rating for some products and services, multiple rates for various goods and services, increased government transfers, and additional tax credits. Inflationary concerns have been expressed over the VAT since it could increase the price of goods to the ultimate consumer although those fears have been largely dismissed.

Most value added taxes have at least two rates: the basic positive rate and a zero rate. In many countries there has been extensive discussion over the use of multiple positive rates as a means of making the tax more progressive and dampening luxury consumer spending. While zero rating of basic foods and a few other items is without question effective in lessening the burden on the poor and regressivity, there is substantial evidence that multiple rates contribute little toward progressivity (Due, 1990). There are numerous objections to the use of multiple rates, as explained effectively by Tait (1988), though there may be justification for high rates on a few commodities. However, three-fifths of all VAT systems currently in operation have more than one tax rate, mainly on grounds of equity (Agha and Haughton, 1996). Particularly in developing countries, simplicity in the operation of a VAT is essential for its effectiveness, and thus the case for a single rate is very strong.

If the VAT becomes a viable tax for the electronic commerce debate it must address services. Most sales taxes worldwide apply to all commodities except those specifically excluded, but only to specified services, and this rule has been carried into many value added taxes (Cnossen, 1989). The issue of whether tax should apply to all ser- 
vices except those excluded or only those specified has been debated in various countries, and some have shifted from the latter approach to the former before the law was enacted (Trinidad and Tobago is an example). The main reason for the specification approach is simply that many services are not regarded as suitable for taxation, either for social policy reasons (medical, dental, hospital, educational, and even legal) or for administration reasons, because of the very small scale, non-commercial nature of the establishments. But this in itself does not make the specification approach essential; the danger of its use is that the listing will let various services for which there is no strong justification for exclusion slip out from under the tax.

\section{International Service Issues}

Under the basic rule, tax would be collected at importation, and the firms would receive credit for this tax and a refund at the time of export of the products. But there is often strong pressure for exempting the inputs to reduce working capital requirements for these export-oriented firms, particularly if there is a delay in paying refunds. If compliance is complete there is no net revenue loss to the government from exemption, except for the interest on the sums that would be paid ahead of the time the input tax credit would be given. But there are dangers from exemption. This practice will make more difficult the development of domestic production of inputs now being imported -- unless these purchases are zero rated --and add one more complication to the tax (Due 1990). Exemption removes the tax from imported inputs, but not off domestic inputs; to do so requires zero rating. Furthermore, there is always danger that some of the goods imported tax free will leak into the domestic market, other than through registered firms. On the whole there is merit in not exempting these inputs -- but the pressure is strong.

A number of questions arise with respect to international transport. If domestic tickets are taxable and international ones are not, a problem arises with respect to trips that are partly domestic, partly international. There are also questions relating to various sales and services to international carriers, both air and sea. Some countries, for example, do extensive servicing and repair for foreign airlines and cruise ships, as well as providing supplemental fuel. Are these to be defined as export transactions? There is merit in doing so, in part because much of the business may be lost to neighboring countries if this policy is not followed. There is always some danger that the goods may leak back into domestic use without payment of tax. Some of the most difficult problems arise with regard to other types of services which take on an international character: a public accounting, law, or managerial consulting firm in one country provides services in another country. Rendering of services in another country is basically an export transac- tion, and should be subject to zero rating. But questions arise as to what "performed in another country" means. Often much of the work, and perhaps all of it (preparing plans for a new factory, for example) will be performed in the home country. The basic rule that appears most satisfactory is one based on where the benefits of the service are realized, not on where the work is done. As an export transaction, credit would be allowed for input tax paid.

There are other problems with certain types of international transactions. For example, if tours are taxable, which country has the appropriate claim, the country where the tour is booked and paid for, or the country in which the tour occurs? The latter choice is more logical, but difficult to enforce. Magazine subscriptions also create operational problems. Typically magazine subscriptions within the country are taxable, as are individual purchases of magazines. But customers may order magazine subscriptions from publishers or distributors outside the country. These should be subject to tax. But it is not feasible to collect the tax when the individual magazines enter the country (bulk shipments for distribution within the country can be taxed), and there is no way to ensure that tax is paid on the subscription - in the absence of rigidly enforced exchange controls.

For e-commerce transactions of traditional/tangible products do not present significant difficulty since the goods are generally taxed as they "cross the border." The real problem is the taxation of the non-traditional/ intangible goods. The issues for those products parallel those of the service sector but are compounded. Services can be considered a form of intangible good. This has been extensively explored in the GATS (General Agreement for Trade in Services) talks of the WTO. Interestingly, many services that have been delivered via traditional means can and are being delivered on-line (e.g. consulting, architectural, and medical to name a few) as is the case with books, music, and video. If these "goods" are considered tangible products then they will be taxed at each stage of their production. Hence, the resources used to create the product will be incorporated into the cost and taxed - under VAT - by the respective authority as would be any other product. If the product is exported, the company under certain VAT regimes - is entitled to a rebate of that tax. Assuming that the two countries recognize the taxation authority of the other, the country of import would have a claim - including the paper trail - to seek their tax payment. The true difficulty of this scheme is that digital transactions are almost impossible to trace and unless a single company is conducting a substantial amount of business in a given country the rewards might outweigh the benefits. This has been made clear under current tax regimes. 


\section{Conclusion}

This paper has reviewed the key issues associated with the taxation of electronic commerce, both domestically in the United States and broader issues in the European Union. The domain of these issues is not limited to North America and Europe but have much greater implications when Internet penetration rates are examined in the developing world. Since the taxation issue is one that is shrouded in politics and court battles, the ultimate resolution of these issues is not at hand. In the meantime, the solutions explored provide the groundwork through which all parties can reach an agreement. Experts anticipate a resolution based in part on the SSTP, providing businesses with incentives to voluntarily comply with simplified regulations, tax rates, and automated collection system. The VAT affords an overall solution but requires a more comprehensive reorganization of both the federal income tax and state sales tax system. It is therefore unlikely that this option will provide a near term solution to the situation.

\section{References}

Agha, A. and Haughton, J. (1996). "Designing VAT Systems: Some Efficiency Considerations." Review of Economics and Statistics, 78(2), 303-309.

Buckett, A. (1992). VAT in the European Union. Butterworths:London.

Cnossen, S. (1989). "What Rate Structure for a Value Added Tax?" National Tax Journal, 35(2), 205-214.

Due, J.F. (1990). "Some Unresolved Issues in Design and Implementation of Value Added Taxes." National Tax Journal, 43(4), 383-395.

Gale, W. G. (1995). "Building a Better Tax System." Brookings Review, 13(4), 18-24.

Government Accounting Office (2000). Sales Taxes: Electronic Commerce Growth Presents Challenges; Revenue Losses are Uncertain.

Henn, H. and Alexander, J. (1983) Laws of Corporations and Other Enterprises. West Publishing: ST Paul.

Joint Committee on Taxation. (1992). Comparison of the Tax Systems of the United States, Germany, and Japan. JCS-13-92.

Lilley, W. and DeFranco, L.J. (1999). State, County and City Sales. iMap.com, Inc.

Metcalf, G.E. (1995). "Value-added Taxation: A tax Whose Time Has Come?” Journal of Economic Perspectives, 9(1), 121-141.

Organization for Economic Cooperation and Development (OECD) (2001a) Treaty Characterization Issues Arising from ECommerce. Http://www.OECD.org
Organization for Economic Cooperation and Development (OECD) (2001b) Consumption Tax Aspects of EC.

Http://www.OECD.org

Pechman, J. (1987). Federal Tax Policy. Brookings Institution: Washington.

PriceWaterhouseCoopers, Financial Management Benchmarking Programme (2001) (http://www.excelsior.pwcglobal.com/utils /downloads/Financial-Benchmarking.pdf).

Tait, A. (1988). Value Added Tax. International Monetary Fund:Washington.

U.S. Department of Commerce (1999). Quarterly Summary of State and Local Tax Revenue. Bureau of the Census, Government and Finance Branch. (Dec. 14, 1999).

\section{Biography}

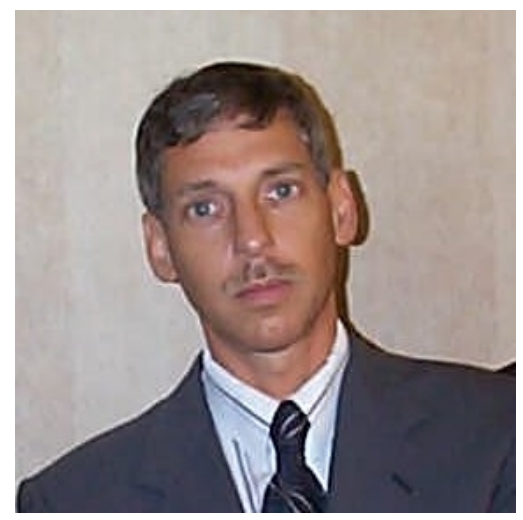

Steven John Simon is an associate professor in the Stetson School of Business and Economics at Mercer University in Atlanta, Georgia. He received his Ph.D. from the University of South Carolina, specializing in MIS and International Business. Before entering the doctoral program he spent eighteen years in the private sector in management/computer operations and was owner/operator of seven McDonalds franchises. His current research interests include information determinants of international business structures, enterprise information systems, supply chain management, electronic commerce in the international environment, and organization change and learning. Dr Simon is also an officer in the United States Navy Reserve formerly assigned to the directorate of logistics for United States Atlantic Command. His past Navy assignments included serving as Information Resource Management Officer to the Commander of the Second Naval Construction Brigade. He has consulted and lectured extensively in Korea, Hong Kong, Malaysia, Singapore, and the People's Republic of China. He has previously published in Information Systems Research, Journal of Applied Psychology, Communications of the CAM, Database, European Journal of Information Systems, The Journal of Global Information Technology Management, The Journal of Global Information Management, Journal of Informaion Technology Cases and Applications, and The Information Resources Management Journal. 